Urszula Kurcewicz

ORCID: 0000-0001-5808-9851

\title{
Znaczenie tradycyjnych źródeł informacji w działalności infobrokerskiej
}

\section{SŁOWA KLUCZOWE:}

infobroker, tradycyjne źródto informacji, proces informacyjny, archiwa, biblioteczne zbiory specjalne

\section{W prowadzenie}

Rozwój techniki digitalizacji pozwolił na udostępnianie na masową skalę informacji przechowywanych w pierwotnej formie na tradycyjnych nośnikach, głównie na papierze czy w różnego rodzaju formach utrwalania obrazu i dźwięku. Pomimo ogromnego postępu w dziedzinie digitalizacji znaczna liczba informacji dostępna jest nadal wyłącznie w pierwotnej formie. Dostęp do tej części zasobów wiedzy ludzkiej dla infobrokera możliwy jest za pośrednictwem instytucji, zarówno państwowych, jak i prywatnych, wyspecjalizowanych w zabezpieczaniu, przechowywaniu i udostępnianiu pierwotnych form informacji czy też stworzonych na ich podstawie dokumentów pochodnych i wtórnych.

Badania polskiego rynku informacji wskazują, że wśród najczęściej otrzymywanych przez firmy infobrokerskie zleceń znajdują się: wyszukiwanie informacji i publikacji naukowych, tworzenie bibliografii do prac naukowych, wyszukiwanie danych historycznych/archiwalnych czy przygotowywanie opracowań prasowych ${ }^{1}$. Rzetelne sprostanie tego typu

1 B. Baczyńska, K. Grabarz, S. Machlowski, Jak zostać brokerem informacji? Wybrane aspekty praktyczne, [w:] S. Cisek, A. Januszko-Szakiel (red.), Zawód infobroker. Polski rynek informacji, Warszawa 2015, s. 100. 
zamówieniom klientów wymaga od infobrokera umiejętności wyszukiwania, klasyfikowania i przetwarzania informacji pochodzacych z tradycyjnych źródeł informacji, Internet zaś staje się dla nich źródłem komplementarnym. Infobroker powinien posiadać wiedzę o sieci krajowych i zagranicznych archiwów, bibliotecznych zasobach specjalistycznych czy materiałach przechowywanych w różnego rodzaju repozytoriach danych. Ważne jest, aby również orientował się w zasadach udostępniania i przetwarzania zgromadzonych przez te instytucje materiałów.

Celem artykułu jest wskazanie wagi biegłego wyszukiwania i przetwarzania informacji pochodzących z ich tradycyjnych źródeł jako niezbędnego elementu bazy umiejętności osoby wykonującej zawód infobrokera. W tym celu autorka podjęła się systematyzacji typologii tradycyjnych źródeł informacji oraz uporządkowania terminologii omawianej problematyki. W artykule ukazane zostały poszczególne etapy procesu informacyjnego z perspektywy kształcenia przyszłych adeptów infobrokeringu. Druga część tekstu odnosi się do tworzenia oraz doskonalenia indywidualnego warsztatu informacyjnego infobrokera.

\section{Informacja i proces informacyjny}

Istotą rozwoju komunikowania międzyludzkiego jest pojawianie się nowych kanałów komunikacyjnych. Szczególny postęp w tej dziedzinie przyniosła rewolucja technologiczna $\mathrm{XX}$ wieku, wynalazek radia $\mathrm{i}$ telewizji, a następnie Internetu i telefonii cyfrowej. Wprowadzenie nowych środków przekazu doprowadziło do powstania podziału na tzw. stare i nowe media. Analogicznie do niego w rozróżnieniu źródeł informacji zaczęto używać terminów „stare” i „nowe” źródła informacji. Jednakże pojawienie się tych nowych nie doprowadziło do unicestwienia starych, gdyż to one zachowują w sobie większość zgromadzonej wiedzy ludzkiej. Jako dziedzictwo kulturowe ludzkości przechowywane są pieczołowicie w bibliotekach, archiwach czy muzeach, służąc kolejnym pokoleniom badaczy. Wypracowano natomiast nowe formy dostępu do informacji w nich zawartych, których funkcjonowanie w obiegu informacyjnym umożliwiła technologia cyfrowa.

Termin „informacja” zarówno w naukowym znaczeniu, jak i w potocznym rozumieniu ma wiele interpretacji. Jest to pojęcie, którego naukowe zdefiniowanie napotyka na znaczne trudności. W poszczególnych dyscyplinach naukowych jego definicje istotnie od siebie odbiegają. Jerzy Ratajewski podaje, że do lat 80. XX wieku w nauce funkcjonowało już 
ponad 400 różnych definicji tego pojęcia². Wśród nich wyróżnić można dwie główne grupy: definicje cybernetyczne i definicje informatyczne.

W ujęciu cybernetycznym uznaje się, że informację stanowi: „[...] każdy czynnik zmniejszający stopień niewiedzy o badanym zjawisku, umożliwiający człowiekowi i innemu organizmowi żywemu lub urządzeniu lepsze poznanie otoczenia i przeprowadzenie w sprawniejszy sposób celowego działania. Inaczej mówiąc, informacją będzie wszelka treść zaczerpnięta z otaczającej rzeczywistości, zmieniająca stan danego obiektu na inny"3.

Ujęcie informatyczne zakłada, że: „[...] informacją jest znaczenie (treść) przypisywane danym, przez które rozumie się liczby, fakty, pojęcia lub rozkazy przedstawiane w sposób wygodny do przesyłania, interpretacji lub przetwarzania metodami ręcznymi względnie automatycznymi” 4 .

Cechami informacji jako zasobu społecznego są: niematerialność, niezużywalność, kumulowalność oraz odnawialność.

Podkreślić należy, iż termin „informacja” może być rozumiany trojako:

- jako wiadomość (wskazówka, pouczenie), czyli każda treść mająca znaczenie i stanowiąca odbicie rzeczywistości (zaczerpnięta ze świata zewnętrznego człowieka) lub ją zastępująca (ze świata wewnętrznego);

- czynność powiadomienia lub zakomunikowania czegoś;

- instytucja informująca o czymśs.

W odniesieniu do infobrokeringu informację powinno traktować się jako wiadomość uporządkowaną, przeanalizowaną, przekazaną odbiorcy w odpowiedniej, zrozumiałej dla niego postaci, na którą ten zgłaszał wcześniej potrzebę w związku z realizacją określonych celów ${ }^{6}$.

Jak zaznacza Aneta Januszko-Szakiel, działalność brokera informacji polega na: „[...] pozyskiwaniu, ocenie, weryfikacji, analizie i odpłatnym dostarczaniu informacji jawnoźródłowych ( $\mathrm{tj}$. jawnych i pozyskanych

2 J. Ratajewski, Informologia - nauka o informacji, [w:] A. Jarosz (red.), Informacja naukowa, bibliotekarstwo, zagadnienia wydawnicze, Prace Naukowe Uniwersytetu Śląskiego. Studia Bibliologiczne, t. V, Katowice 1992, s. 9.

3 H. Batorowska, B. Czubała, Wybrane zagadnienia nauki o informacji i technologii informacyjnej, Kraków 1996, s. 9.

4 Tamże.

5 J. Ratajewski, Informologia..., s. 10-11.

6 G.K. Świderska (red.), Informacja zarządcza $w$ procesie formułowania $i$ realizacji strategii firmy. Wyzwania dla polskich przedsiębiorstw, Warszawa 2003, s. 52. 
legalnie) ludziom i organizacjom zgłaszającym zapotrzebowanie na usługę infobrokerską"7.

Termin „przetwarzanie informacji” oznacza wszystkie operacje przeprowadzone w procesie obiegu informacji. Takimi procesami są: wydobywanie informacji ze źródła, przekazywanie oraz utrwalanie ${ }^{8}$.

Działalność informacyjna polega na organizowaniu i doskonaleniu przepływu informacji, przy czym występuje zastrzeżenie, iż przekazywanie informacji nie jest czynnością jednorazową, lecz wielokrotną i powtarzalną. Inaczej ujmując, działalność informacyjna określana jest jako zorganizowana działalność, której zadaniem jest gromadzenie, opracowanie i udostępnienie informacji o osiagnięciach nauki, techniki i innych dziedzinach życia społecznego ${ }^{9}$.

Termin „służba informacyjna” odnosi się bądź do instytucji prowadzących działalność informacyjną, bądź do zespołu pracowników zatrudnionych w instytucjach prowadzących działalność informacyjną. Do najważniejszych zadań służby informacyjnej należą:

- informacja o dokumentach gromadzonych i przechowywanych w danej placówce;

- informacja o treści tych dokumentów;

- dokumentacja zbiorów własnych i innych placówek poprzez opracowania formalne, rzeczowe, analityczno-syntetyczne tych zbiorów;

- działalność wydawnicza;

- działalność dydaktyczno-metodyczna;

- propaganda ośrodka informacji i jego zbiorów ${ }^{10}$.

7 A. Januszko-Szakiel, Informacja tworzywem przekazów infobrokerskich. Wybrane zagadnienia, [w:] S. Cisek, A. Januszko-Szakiel (red.) Zawód infobroker..., s. 278.

$8 \mathrm{~W}$ procesie obiegu informacja ulega różnego rodzaju przekształceniom, np. nadawca może modyfikować postać informacji w celu jej zapisania lub przekazania, odbiorca zaś w celu jej odebrania i zrozumienia. E. Chmielewska-Gorczyca, B. Sosińska-Kalata, Informacja naukowa z elementami naukoznawstwa, Warszawa 1991, s. 27.

9 W kontekście tematu niniejszego artykułu działalność informacyjną należy oddzielić od działalności dokumentacyjnej, która jest pojęciem węższym i najczęściej jest rozumiana dwojako. Po pierwsze - jako część działalności informacyjnej związanej z gromadzeniem i opracowywaniem dokumentów, po drugie - jako zbiór lub spis dokumentów dotyczących określonego zagadnienia bądź dobranych według innych kryteriów, np. dokumentacja zbiorów własnych biblioteki. Podstawę działalności dokumentacyjnej stanowią dokumenty, czyli materialne nośniki, na których została utrwalona informacja w znaczeniu wiadomości. M. Dembowska, Dokumentacja i informacja naukowa. Zarys problematyki i kierunki rozwoju, Warszawa 1965, s. 51-52.

10 H. Batorowska, B. Czubała, Wybrane zagadnienia nauki..., s. 11. 
Infobroker w realizacji zapotrzebowań informacyjnych klientów powinien biegle korzystać z informacji naukowej - stanowi to jedną z podstawowych kompetencji w ramach wyszukiwania źródeł informacji. Termin „informacja naukowa” oznacza: informację o osiagnnięciach nauki; informację przeznaczoną dla pracowników nauki; informację opracowaną metodą naukową; dziedzinę wiedzy obejmującą całokształt zagadnień teoretycznych i praktycznych związanych z działalnością informacyjną ${ }^{11}$. W tym ostatnim znaczeniu termin „informacja naukowa” w literaturze problemu stosowany jest wymiennie z terminami: „informatologia” bądź „informologia” 12 .

Proces informacyjny składa się z kolejnych etapów: gromadzenia, opracowywania, przechowywania, wyszukiwania, przekazywania i wdrażania informacji.

\section{Rysunek 1. Etapy procesu informacyjnego}

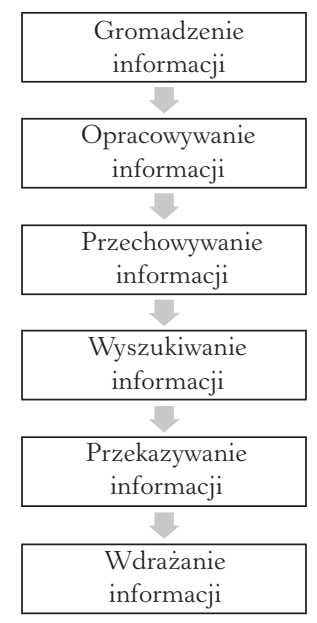

Źródło: opracowanie własne na podstawie: H. Batorowska, B. Czubała, Wybrane zagadnienia nauki o informacji i technologii informacyjnej, Kraków 1996, s. 32-33.

11 Tamże, s. 11-12.

12 Jerzy Ratajewski definiuje informologię jako naukę o informacji i informowaniu, obejmującą zarówno zagadnienia ogólnej teorii informologii, jak i poszczególnych dziedzin ze szczególnym uwzględnieniem informologii nauki. J. Ratajewski, Wybrane problemy metodologiczne informologii nauki (informacji naukowej), Katowice 1994, s. 32-49. Z kolei Maria Dembowska podaje, że: „Przedmiotem informatologii jest działalność naukowo-informacyjna, której zadanie polega na udostępnianiu wyników nauki lub osiągnięć praktyki w celu wykorzystania tych zdobyczy dla dalszego rozwoju nauki, kultury, gospodarki. Informatologia zajmuje się całokształtem zagadnień teoretycznych i praktycznych związanych z działalnością naukowo-informacyjną”, M. Dembowska, Nauka o informacji naukowej (informatologia). Organizacja i problematyka badan w Polsce, Warszawa 1991, s. 22-26. 
Pierwszy etap procesu informacyjnego stanowi gromadzenie informacji obejmujące zespół czynności, takich jak: uzyskanie informacji o dokumencie, jego nazwanie i finalnie wprowadzenie do zbioru informacyjnego ${ }^{13}$. W drugim etapie następuje przygotowanie zawartości zbioru informacyjnego do udostępniania, polega ono na: wprowadzaniu, katalogowaniu, klasyfikowaniu, analizowaniu, przygotowaniu technicznym dokumentów oraz sporządzeniu opracowań dokumentacyjnych, na podstawie których możliwy będzie dostęp do konkretnych dokumentów. Przechowywanie informacji jest trzecim etapem procesu informacyjnego, odbywa się w sposób adekwatny dla danych nośników pamięci, na przykład w formie papierowej pierwotnej czy w formie mikrofilmów, a obecnie również pod postacią cyfrową. Na etapie czwartym - wyszukiwania informacji - przeprowadzana jest kwerenda informacyjna, czyli proces polegający na porównywaniu zapytań informacyjnych użytkowników, sformułowanych na przykład w postaci zapytań hasłowych, z zasobami zbioru informacyjnego. Przedostatni etap to przekazywanie (udostępnianie) informacji określonemu odbiorcy. Ostatni etap procesu informacyjnego to wdrażanie informacji, podczas którego użytkownik sprawdza przydatność uzyskanych informacji, wartościuje je i wykorzystuje w praktyce ${ }^{14}$.

Miejsce infobrokera w procesie informacyjnym może być dwojakie. $\mathrm{Z}$ jednej strony jest on użytkownikiem zasobów wyspecjalizowanych instytucji, takich jak biblioteki czy archiwa, z drugiej strony, realizując zamówienie klienta, przechodzi przez wszystkie etapy procesu informacyjnego, gromadząc i opracowując informację do wdrożenia w formie końcowej, która optymalnie zaspokaja potrzeby informacyjne zamawiającego.

\section{Klasyfikacja źródeł informacji}

Współczesna nauka o informacji czerpie z dorobku nauk historycznych, w odniesieniu do metodologii historii formułuje definicje dokumentu oraz źródła informacji oraz proponuje ich klasyfikację. W naukach historycznych obok terminu „źródło historyczne” równoprawnie funkcjonuje określenie „nośnik pamięci historycznej” ${ }^{15}$. Jak pisze Henryk Dominiczak:

13 Zbiór informacyjny definiowany jest jako uporządkowany zbiór dokumentów stanowiący podstawę działalności informacyjnej.

14 H. Batorowska, B. Czubała, Wybrane zagadnienia nauki..., s. 32-33.

15 Szerzej: M. Kula, Nośniki pamięci historycznej, Warszawa 2002. 
„Źródłem jest to wszystko, co zachowało się z czasów minionych, co może służyć badaniom historyka, co odzwierciedla splot określonych stosunków, które niegdyś istniały w określonym miejscu, czasie i środowisku" 16.

Sformułowania uniwersalnej definicji pojęcia źródła historycznego na przestrzeni wieków podejmowało się wielu badaczy. W nauce polskiej krytyczny przegląd tych definicji przeprowadził Jerzy Topolski, a do jego ustaleń odwołują się kolejne generacje historyków. Jak zaznacza J. Topolski, definicje źródła historycznego generalnie można podzielić na jednoi dwuczłonowe. W definicjach jednoczłonowych historycy wskazywali tylko na ślady (synonimicznie rezultaty, wytwory, pozostałości) działania, ewentualnie także samego istnienia człowieka, natomiast w definicjach dwuczłonowych źródło historyczne jest nie tylko pozostałością po celowej pracy człowieka, lecz stanowi także odbicie tej działalności w aspekcie poziomu świadomości społeczeństwa oraz w aspekcie przejawów rozwoju kultury w czasie, kiedy to źródło powstało ${ }^{17}$.

Sam J. Topolski proponuje szerokie ujęcie pojęcia, w którym: „[...] źródłem historycznym są wszelkie źródła poznania historycznego (bezpośredniego i pośredniego), tzn. wszelkie informacje (w rozumieniu teorioinformacyjnym) o przeszłości społecznej, gdziekolwiek one się znajduja, wraz z tym, co owe informacje przekazuje (kanałem informacyjnym). Przeszłość społeczna, rzecz jasna, rozumiana jest tutaj szeroko, obejmując równiė̇ warunki naturalne, w których żył człowiek"18.

Klasyfikacje źródeł poznania historycznego, podobnie jak omówione podejścia definicyjne, kształtowały się od epoki średniowiecza, dzieląc środowisko historyków na zwolenników odmiennych koncepcji typologizacji. J. Topolski wskazuje na dwie wiodące klasyfikacje dychotomiczne:

16 H. Dominiczak, Zarys metodologii historii, Częstochowa 1995, s. 91.

17 J. Topolski, Metodologia historii, Warszawa 1984, s. 323. Przykładem definicji jednoczłonowej jest propozycja Marcelego Handelsmana zawarta w pracy z 1928 r., w której uczony źródłem historycznym nazywa: „utrwalony i zachowany ślad myśli, działania lub najogólniej życia ludzkiego”, M. Handelsman, Historyka. Zasady metodologii i teorii poznania historycznego, oprac. P. Węcowski, Warszawa 2010, s. 44. Uznaną w literaturze polskiej definicję dwuczłonową źródła historycznego w okresie powojennym zaproponował Gerard Labuda, który pisze, iż tym określeniem: „nazwiemy wszystkie pozostałości psychofizyczne i społeczne, które będąc wytworem pracy ludzkiej, a zarazem uczestnicząc w rozwoju życia społeczeństwa, nabierają przez to zdolności odbijania tego rozwoju. Wskutek tych swych właściwości (tj. wytworu pracy i zdolności odbijania) źródło jest środkiem poznawczym, umożliwiającym naukowe odtworzenie rozwoju społeczeństwa we wszystkich jego przejawach”, G. Labuda, Próba nowej systematyki i nowej interpretacji zródet historycznych, „Studia Źródłoznawcze” 1957, t. I, s. 22.

18 J. Topolski, Metodologia..., s. 324. 
- podział na źródła bezpośrednie i pośrednie;

- podział na źródła pisane i niepisane ${ }^{19}$.

Do zwolenników pierwszego podziału należeli między innymi Johann Gustav Bernhard Droysen i Ernst Bernheim, w Polsce opowiadano się głównie za drugim podejściem, jego rzecznikami byli między innymi Joachim Lelewel i Stanisław Kościałkowski20. Marceli Handelsman uznawał za zasadne oba podziały. W kwestii klasyfikacji źródeł informacji widoczne są odniesienia do prac tego historyka we współczesnych polskich studiach informatologicznych. Stąd w niniejszym tekście zasadne wydaje się przytoczenie klasyfikacji źródeł przez niego opracowanej (i zobrazowanie jej odpowiednim schematem - rys. 2) ${ }^{21}$. M. Handelsman dzielił źródła historyczne na niepisane, rzeczowe, pozostałościowe (źródła materialne) oraz na materiały źródłowe w formie pisanej lub drukowanej. Do źródeł materialnych niepisanych zaliczał:

- środowisko naturalne przekształcone wskutek celowej działalności człowieka (na przykład sieć dróg komunikacyjnych);

- narzędzia pracy służące do przeobrażania środowiska naturalnego (na przykład narzędzia rolnicze);

- wytwory użytkowe, takie jak: ubiory, przedmioty codziennego użytku czy broń;

- zabytki architektury drewnianej i murowanej;

- miejsca pochówku (cmentarzyska i grobowce);

- pomniki wystawiane ku czci wybitnych postaci czy upamiętniające wydarzenia historyczne ${ }^{22}$.

Druga główną grupę źródeł w podziale Handelsmana stanowiły źródła pisane lub drukowane. $\mathrm{W}$ ich obrębie historyk wyróżniał opisy i akta. Akta rozumiał jako dokumenty bądź ustanawiające pewną czynność lub stwierdzające jej istnienie w stosunkach między ludźmi, bądź będące pisanym wyrazem czynności, w szczególności czynności prawnej. Aktami są wszelkiego rodzaju świadectwa i zaświadczenia urzędowe, umowy najmu, umowy o pracę itd. Wśród źródeł opisowych J. Handelsman wyróżniał trzy kategorie: opisy dziejopisarskie (roczniki, kroniki, historie), opisy pamiętnikarskie (dzienniki, biografie, wspomnienia, listy, pamiętniki), zbiory wiadomości (prasa - dzienniki, tygodniki i miesięczniki).

19 Tamże, s. 328-329.

20 H. Dominiczak, Zarys metodologii..., s. 103.

21 M. Handelsman, Historyka. Zasady metodologii..., s. 44-50.

22 Tamże. 
Rysunek 2. Podział źródeł historycznych według Marcelego Handelsmana

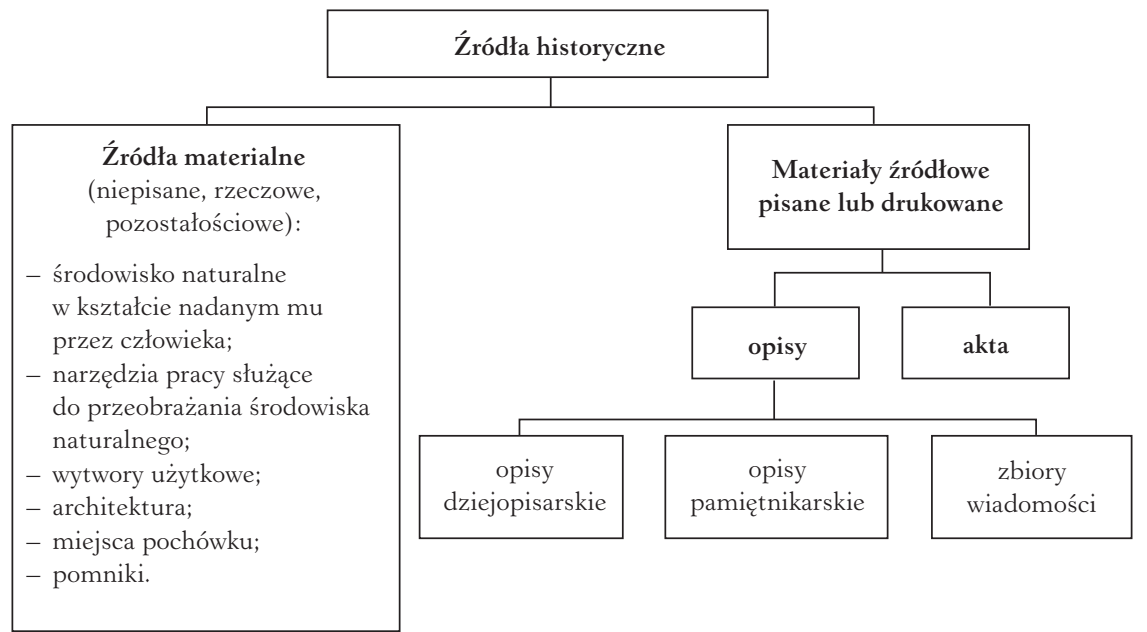

Źródło: opracowanie własne na podstawie: M. Handelsman, Historyka. Zasady metodologii i teorii poznania historycznego, oprac. P. Węcowski, Warszawa 2010, s. 44-50.

W naukach historycznych za bardzo istotną poznawczo grupę źródeł uznaje się ikonografię - ryciny, obrazy, przedstawienia miast, pieczęcie, herby, środki płatnicze itd. - jest to grupa źródeł historycznych ułatwiająca poznanie wielu zjawisk przeszłości, które w formie oryginalnej nie zachowały się do czasów współczesnych. Rozwój techniki w XIX i XX wieku wprowadził szereg nowych nośników pamięci historycznej: fotografię, radio, kinematografię, które stanowią nieocenione źródła informacji o minionym czasie ze względu na fakt, iż pozwalały na bieżące rejestrowanie zjawisk.

We współczesnej nauce o informacji za dokument uważa się informację wraz z materiałem, na którym została utrwalona. Zgodnie z kryterium formy zapisu wyróżnia się dokumenty piśmiennicze i dokumenty niepiśmiennicze. Dokumenty piśmiennicze zawierają treść utrwaloną na dowolnym materiale (w czasach nowożytnych najczęściej papierze) pod postacią tekstu słownego (pisma lub druku) bez względu na kod (język), w jakim zostały zapisane. W dokumentach niepiśmienniczych treść wyrażona jest w postaci obrazu lub dźwięku bądź w formie mieszanej. Pierwsza grupa, dokumenty oglądowe (wizualne), odbierane są przez adresata wyłącznie za pośrednictwem wzroku, należą do niej fotografie, przeźrocza, rysunki, obrazy, grafiki, modele, eksponaty muzealne, nieme filmy itd. Dokumenty słuchowe (audialne) przekazują treść za pomocą dźwięku i odbierane są poprzez zmysł słuchu, do tej grupy zalicza się 
formy zapisu dźwiękowego, takie jak płyty gramofonowe, różnego rodzaju taśmy. Najbardziej typowym przykładem dokumentów oglądowosłuchowych (audiowizualnych) są filmy dźwiękowe. W związku z rozwojem technik reprodukcji podział dokumentów piśmienniczych na publikowane i niepublikowane ma coraz bardziej umowny charakter.

\section{Rysunek 3. Klasyfikacja dokumentów według formy zapisu}

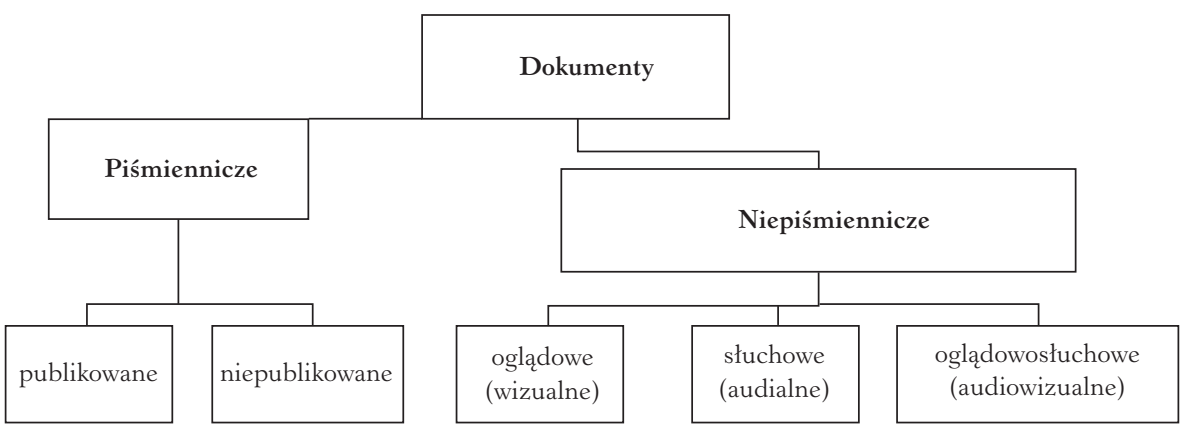

Źródło: opracowanie własne na podstawie: H. Batorowska, B. Czubała, Wybrane zagadnienia nauki o informacji i technologii informacyjnej, Kraków 1996, s. 35.

\section{Rysunek 4. Typy dokumentów pochodnych}

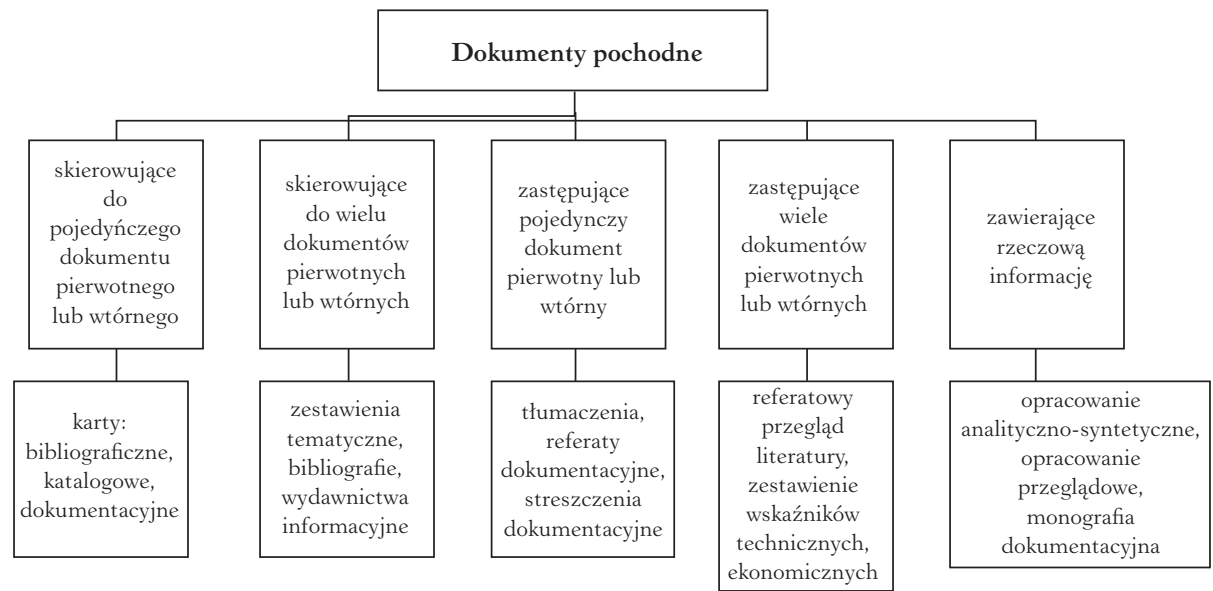

Źródło: opracowanie własne na podstawie: K. Sosnowska, Pomoce do nauczania przedmiotu „Opracowanie dokumentacyjne źródet informacji”. Ćwiczenia. Sprawdziany, Warszawa 1980, s. 21 .

Drugim podstawowym kryterium podziału dokumentów są sposób przygotowania i stopień przetworzenia treści. Na ich podstawie 
Tabela 1. Systematyka typologii dokumentów

\begin{tabular}{|c|c|}
\hline Kryterium & Typy dokumentów \\
\hline Kryterium zastosowanego kodu & $\begin{array}{l}\text { - } \quad \text { piśmiennicze } \\
\text { - niepiśmiennicze }\end{array}$ \\
\hline $\begin{array}{l}\text { Kryterium pochodzenia i sposobu } \\
\text { powstawania }\end{array}$ & $\begin{array}{l}\text { - } \text { pierwotne (prymarne) } \\
\text { - pochodne } \\
\text { - wtórne }\end{array}$ \\
\hline Kryterium nośnika fizycznego & $\begin{array}{l}\text { - } \quad \text { konwencjonalne } \\
\text { - } \quad \text { zminiaturyzowane }\end{array}$ \\
\hline $\begin{array}{l}\text { Kryterium zasięgu } \\
\text { upowszechniania }\end{array}$ & $\begin{array}{l}\text { - } \quad \text { opublikowane } \\
\text { - nieopublikowane }\end{array}$ \\
\hline Kryterium stopnia dostępności & $\begin{array}{l}\text { - } \text { publikacje powszechnie dostępne } \\
\text { - } \text { publikacje o ograniczonym udostępnianiu } \\
\text { - } \quad \text { publikacje do użytku wewnętrznego }\end{array}$ \\
\hline Kryterium cech wydawniczych & $\begin{array}{l}\text { - } \\
\text { - } \\
\text { nieperiodycznedyczne }\end{array}$ \\
\hline Kryterium formy wydawniczej & $\begin{array}{l}\text { - wydawnictwa samoistne } \\
\text { - utwory } \\
\text { - fragmenty }\end{array}$ \\
\hline Kryterium formy piśmienniczej & $\begin{array}{l}\text { - monografie (oryginalne i kompilacyjne) } \\
\text { - doniesienia, komunikaty } \\
\text { - } \text { teksty źródłowe } \\
\text { - } \text { publicystyka } \\
\text { - } \text { podręczniki } \\
\text { - } \quad \text { spisy bibliograficzne } \\
\text { - } \quad \text { słowklopedie } \\
\text { - }\end{array}$ \\
\hline Kryterium biblioteczne & $\begin{array}{ll}\text { - } & \text { wydawnictwa zwarte } \\
\text { - } & \text { wydawnictwa ciagłe } \\
\text { - } & \text { zbiory specjalne }\end{array}$ \\
\hline $\begin{array}{l}\text { Kryterium przeznaczenia } \\
\text { czytelniczego i zaspokajania } \\
\text { potrzeb }\end{array}$ & $\begin{array}{l}\text { - } \text { naukowe } \\
\text { - } \text { techniczno-ekonomiczne } \\
\text { - } \text { społeczno-polityczne } \\
\text { - } \text { artystyczne } \\
\text { - } \text { społeczno-kulturalne } \\
\text { - dokumenty specjalne, szczególnego rodzaju } \\
\text { i przeznaczenia }\end{array}$ \\
\hline
\end{tabular}

Źródło: opracowanie własne. 
wyróżnia się dokumenty: pierwotne, pochodne i wtórne ${ }^{23}$. Dokumenty pierwotne (prymarne) występują w formie oryginalnej, w jakiej zostały sporządzone przez autora, stanowią podstawę sporządzania dokumentów pochodnych i wtórnych. Dokumenty pochodne sporządzane są na podstawie dokumentów pierwotnych lub wtórnych, zawierają ich charakterystykę formalną lub treściową (bądź obie łącznie). Przedstawiają charakterystykę dokumentu pierwotnego i jego zawartości.

Dokumenty wtórne to dokumenty sporządzone na podstawie dokumentów prymarnych bądź pochodnych, są z nimi identyczne pod względem zawartości treści, często natomiast różnią się w formie zewnętrznej, czego przykładem są mikrofilmy.

We współczesnej literaturze problemu oprócz omówionych powyżej dwóch typologizacji dokumentów wyróżnia się ich podziały na podstawie takich kryteriów, jak: nośnik fizyczny, zasięg upowszechniania, stopień dostępności, cechy wydawnicze, forma wydawnicza, forma piśmiennicza, kryterium biblioteczne oraz kryterium ludzkiej działalności (zaspokajania potrzeb i przeznaczenia czytelniczego). Typologie te zbiorczo ukazuje tabela 1 .

Pojęcie „źródło informacji” jest pojęciem szerszym niż dokument, gdyż oznacza dowolny system wypracowujący informację lub zawierający informacje przeznaczoną do przekazania w celu zaspokojenia potrzeb informacyjnych ${ }^{24}$. Podstawowym współcześnie funkcjonującym podziałem źródeł informacji jest rozróżnienie na źródła dokumentalne (omówione w pierwszej części podrozdziału), źródła instytucjonalne oraz źródła personalne. Dotarcie do odpowiednich źródeł personalnych i instytucjonalnych jest niezwykle cenne w przypadku działalności infobrokerskiej. Personalnymi źródłami informacji mogą być świadkowie wydarzeń historycznych, naukowcy, eksperci, rzecznicy prasowi itd.

Infobroker uzyska kompletny produkt zaspokajający potrzeby klienta pod warunkiem wykorzystania maksymalnej ilości typów źródeł informacji. Ich podstawowe rodzaje obrazuje rysunek 5 .

23 H. Batorowska, B. Czubała, Wybrane zagadnienia nauki..., s. 35.

24 E. Chmielewska-Gorczyca, B. Sosińska-Kalata, Informacja naukowa..., s. 69. 
Rysunek 5. Klasyfikacja źródeł informacji

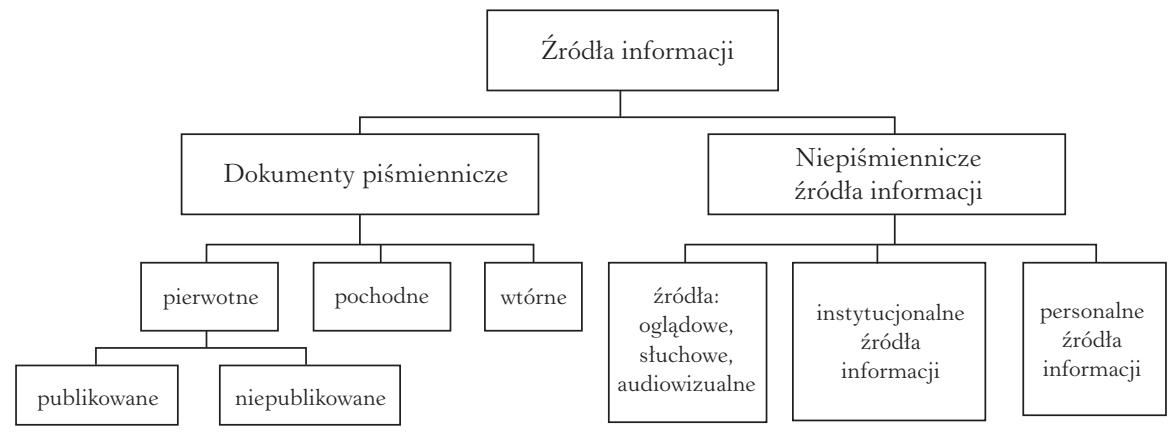

Źródło: opracowanie własne na podstawie: H. Batorowska, B. Czubała, Wybrane zagadnienia nauki o informacji i technologii informacyjnej, Kraków 1996, s. 36.

Dokumenty piśmiennicze pierwotne dzielą się na dokumenty piśmiennicze publikowane (do których należą wydawnictwa zwarte - książki, broszury oraz wydawnictwa ciagłe - czasopisma, wydawnictwa seryjne) oraz specjalne rodzaje wydawnictw (opisy patentowe, normy, literatura firmowa oraz dokumenty życia społecznego ${ }^{25}$ ). W'́ród dokumentów piśmienniczych niepublikowanych znajdują się materiały archiwalne $e^{26}$, rękopisy (maszynopisy), sprawozdania ze zjazdów i konferencji naukowych oraz dysertacje naukowe (nieopublikowane - głównie prace magisterskie i doktorskie) ${ }^{27}$.

\section{Warsztat infobrokera w zakresie wykorzystania tradycyjnych źródeł informacji}

Baza źródłowa wykorzystywana w pracy infobrokera jest w dużym stopniu niejednolita, jej bogactwo wzrastało wraz z następującymi po

25 Terminem „dokumenty życia społecznego” określa się druki wydawane w celu osiągnięcia doraźnych celów informacyjnych, propagandowych, reklamowych i normatywnych, odzwierciedlające wewnętrzną działalność różnego rodzaju organizacji, stowarzyszeń i instytucji oraz grup społecznych. Są to różnego rodzaju ulotki, prospekty, afisze, reklamy. Zwykle przeznaczone są dla określonego kręgu odbiorców i najczęściej do pozaksięgarskiego sposobu rozpowszechniania. Od dokumentów życia społecznego należy odróżnić literaturę patentową, a tzw. literatura firmowa pod postacią katalogów fabrycznych, prospektów, ulotek i folderów może stanowić dokumenty życia społecznego.

26 Materiały archiwalne mogą występować pod postacią drukowanych dokumentów wtórnych, są to najczęściej tematyczne zbiory dokumentów źródłowych.

27 H. Batorowska, B. Czubała, Wybrane zagadnienia nauki..., s. 36. 
sobie epokami, rozwojem techniki i stosunków międzyludzkich. Można stwierdzić wręcz, że badacz czasów najnowszych styka się z nadmiarem i „nadróżnorodnością” źródeł, wśród których wyselekcjonowanie tych stanowiących jądro badanego problemu może stanowić nie lada wyzwanie. Zatem wykonywanie zawodu infobrokera wymaga biegłego poruszania się w dorobku instytucji naukowych powołanych i wyspecjalizowanych w gromadzeniu, przechowywaniu i udostępnianiu źródeł. Wśród nich należy wymienić instytucje obsługujące naukę, takie jak: biblioteki, archiwa naukowe, ośrodki informacji naukowej, technicznej i ekonomicznej. W świetle tytułu niniejszego artykułu szczególną uwagę należy poświecić dwóm instytucjom: bibliotekom i archiwom.

Biblioteka jest najstarszym typem instytucji, która w sposób zorganizowany i systematyczny zajmuje się gromadzeniem, przechowywaniem, opracowywaniem i udostępnianiem informacji. Coraz częściej na czoło zadań pełnionych przez biblioteki wysuwa się ich funkcja informowania o piśmiennictwie, zbiorach bibliotecznych i ich treści. Współcześnie polskie biblioteki wchodzące w skład ogólnokrajowej sieci bibliotecznej mają różny status, są to między innymi biblioteki: naukowe, fachowe, pedagogiczne, publiczne, działające przy szkołach i uczelniach wyższych, instytucji badawczych. W praktyce jedna biblioteka z reguły łączy w sobie cechy dwóch lub kilku rodzajów - na przykład biblioteki naukowej i biblioteki publicznej.

Szczególne miejsce w polskiej sieci bibliotecznej zajmuje Biblioteka Narodowa (BN) powołana po odzyskaniu niepodległości rozporządzeniem Prezydenta Rzeczpospolitej Polskiej z 24 lutego 1928 roku jako centralna biblioteka państwowa ${ }^{28}$. Obecnie zakres działania BN jest bardzo rozległy. Jako centralna biblioteka państwowa inicjuje, organizuje i wykonuje prace międzybiblioteczne, które służą centralnej ewidencji, wymianie i udostępnianiu zbiorów bibliotek z terenu kraju, prowadzi również szeroko rozumianą działalność informacyjną. Biblioteka Narodowa gromadzi i udostępnia czytelnikom: książki z XIX-XXI wieku, czasopisma z XIX-XXI wieku, dokumenty życia społecznego, stare druki, rękopisy, zbiory muzyczne, zbiory dźwiękowe i audiowizualne, dokumenty elektroniczne, zbiory kartograficzne, zbiory ikonograficzne, zbiory bibliologiczne oraz mikrofilmy ${ }^{29}$.

28 Rozporządzenie Prezydenta Rzeczpospolitej Polskiej z 24 lutego 1928 r. O Bibljotece Narodowej, Dz.U. 1928, poz. 183.

29 Oficjalna strona Biblioteki Narodowej w Warszawie - „Zbiory”, https://www.bn.org. $\mathrm{pl} / \mathrm{o}-$ nas/zbiory-bn/zbiory (dostęp: 11.12.2018). 
Dla infobrokera szczególnie cennym przewodnikiem po źródłach są wydawnictwa informacyjne, w tym bibliografie $e^{30}$. Zgodnie z wytycznymi polskiej normy PN-89/N-01225 Rodzaje i części składowe bibliografii uznaje się dwa znaczenia terminu „bibliografia”. W pierwszym jest to uporządkowany zbiór opisów bibliograficznych dokumentów dobranych według określonych kryteriów, którego celem jest informowanie o istnieniu tych dokumentów, na ogół bez względu na miejsce ich przechowywania. W drugim znaczeniu jest to dziedzina wiedzy i działalności praktycznej obejmująca swoim zakresem problemy opisywania dokumentów w celu ich identyfikacji oraz zasady tworzenia i użytkowania bibliografii ${ }^{31}$.

Biblioteka Narodowa prowadzi Polską Bibliografię Narodową, której podstawowym bieżącym członem jest „Przewodnik Bibliograficzny” rejestrujący wydawnictwa zwarte. Do końca 2009 roku wychodził drukiem, obecnie ogłaszany jest w formie plików $\mathrm{PDF}^{32}$.

W obrębie informacji o pozostałych wydawnictwach książkowych BN ogłasza w formie drukowanej „Bibliografię podziemnych druków zwartych z lat 1976-1989” rejestrującą druki zwarte, które zostały wydane poza cenzurą przez nielegalne wydawnictwa, partie polityczne, grupy i ruchy religijne itp. w latach 1976-1989. Bibliografia obejmuje również wydawnictwa Niezależnego Samorządnego Związku Zawodowego „Solidarnośc” w okresie legalnej jego działalności ${ }^{33}$. Bibliografia „Polonica zagraniczne" prezentuje możliwie najbardziej kompletne i aktualne informacje na temat obecności Polski, Polaków i kultury polskiej w światowej produkcji wydawniczej ${ }^{34}$. W ramach informacji o zawartości czasopism prowadzone są: „Bibliografia Wydawnictw Ciągłych”, „Bibliografia Wydawnictw Ciagłych Nowych, Zawieszonych i Zmieniających Tytuł”,

30 Praktyczny wymiar korzystania z bibliografii opisał m.in. Andrzej Chodubski, odsyłając jednocześnie do najważniejszych pozycji bibliograficznych w polskiej literaturze, A.J. Chodubski, Wstęp do badań politologicznych, Gdańsk 2004, s. 84-89.

31 Z. Żmigrodzki, Bibliografia. Metodyka i organizacja, Warszawa 2000, s. 13.

32 Oficjalna strona Biblioteki Narodowej w Warszawie - „Przewodnik Bibliograficzny”, https://www.bn.org.pl/bibliografie/bibliografia-narodowa/przewodnik-bibliograficzny (dostęp: 11.12.2018).

33 Oficjalna strona Biblioteki Narodowej w Warszawie - „Książki polskie podziemne (1976-1989)", https://www.bn.org.pl/bibliografie/bibliografia-narodowa/ksiazki-polskiepodziemne-(1976-1989) (dostęp: 11.12.2018).

34 Oficjalna strona Biblioteki Narodowej w Warszawie - „Polonica zagraniczne”, https:// www.bn.org.pl/bibliografie/bibliografia-narodowa/polonica-zagraniczne (dostęp: 11.12.2018). 
„Bibliografia niezależnych wydawnictw ciagłych z lat 1976-1990” oraz „Bibliografia Zawartości Czasopism”35.

Drugi typ instytucji gromadzących, opracowujących i udostępniających dokumenty źródłowe stanowią, obok bibliotek, archiwa naukowe. W Polsce organem zarządzającym archiwami jest Naczelny Dyrektor Archiwów Państwowych podlegający ministrowi kultury i dziedzictwa narodowego ${ }^{36}$. Centralnym urzędem obsługującym Naczelnego Dyrektora Archiwów Państwowych jest Naczelna Dyrekcja Archiwów Państwowych sprawująca kontrolę nad siecią archiwów państwowych, w skład której wchodzą archiwa centralne: Archiwum Główne Akt Dawnych, Archiwum Akt Nowych, Narodowe Archiwum Cyfrowe ${ }^{37}$ oraz archiwa państwowe zlokalizowane w miastach wojewódzkich wraz z oddziałami i ekspozyturami ${ }^{38}$.

Archiwum Główne Akt Dawnych dysponuje zasobem historycznym obejmującym materiały archiwalne z okresu od XII wieku do I wojny światowej. Oprócz polskich dokumentów przechowywane są w nim archiwalia władz zaborczych oraz archiwa rodzin i osób prywatnych o szczególnym znaczeniu z terenów dawnej Rzeczypospolitej - Korony i Litwy, oraz z poszczególnych zaborów ${ }^{39}$.

Archiwum Akt Nowych przechowuje i udostępnia dokumentację archiwalną wytworzoną po 1918 roku. W jego zasobach znajduje się spuścizna czasów Polski Ludowej. W 1990 roku archiwum przejęło zasób Archiwum Komitetu Centralnego Polskiej Zjednoczonej Partii Robotniczej zawierający akta organów wybieralnych i partyjnego aparatu

35 Oficjalna strona Biblioteki Narodowej w Warszawie - Bibliografia Narodowa, https:// www.bn.org.pl/bibliografie/bibliografia-narodowa (dostęp: 11.12.2018).

36 Ustawa z 14 lipca 1983 r. o narodowym zasobie archiwalnym i archiwach (tekst jedn. Dz.U. 2018, poz. 217).

37 Narodowe Archiwum Cyfrowe powstało w 2008 r. w wyniku przekształcenia Archiwum Dokumentacji Mechanicznej. Obecnie odpowiedzialne jest za digitalizację i dokumentację elektroniczną oraz przechowuje dokumentację fotograficzną i audiowizualną.

38 Oficjalna strona Naczelnej Dyrekcji Archiwów Państwowych, https://www.archiwa.gov. $\mathrm{pl} / \mathrm{pl} / \mathrm{o}-$ nas (dostęp: 10.12.2018).

39 Dużym ułatwieniem w pracy infobrokera są przewodniki i informatory dotyczące zasobu zgromadzonego w Archiwum Głównym Akt Dawnych: D. Lewandowska (red.), Archiwum Główne Akt Dawnych w Warszawie. Informator o zasobie archiwalnym, Warszawa 2008; T. Zielińska (red.), Archiwum Główne Akt Dawnych. Informator o zasobie, Warszawa 1992; J. Karwasińska (red.), Archiwum Gtówne Akt Dawnych w Warszawie. Przewodnik po zespołach, t. I, Archiwa dawnej Rzeczypospolitej, Warszawa 1975; F. Ramotowska (red.), Archiwum Główne Akt Dawnych w Warszawie. Przewodnik po zasobie, t. II, Epoka porozbiorowa, Warszawa 1988. 
wykonawczego - materiały zjazdów, konferencji, narad, plenarnych posiedzeń, w tym Centralnej Komisji Rewizyjnej i Centralnej Komisji Kontroli Partyjnej oraz protokoły Biura Organizacyjnego, Biura Politycznego i Sekretariatu KC PZPR. Do archiwum przekazywana jest dokumentacja archiwalna naczelnych organów władzy państwowej i urzędów centralnych wytworzona po 1989 roku.

Poszukując materiałów archiwalnych, infobroker może zwrócić się również do innych instytucji archiwalnych funkcjonujących w kraju, takich jak:

- Archiwum i Muzeum Pomorskie Armii Krajowej oraz Wojskowej Służby Polek (Fundacja Generał Elżbiety Zawackiej);

- Archiwum Nauki PAN i PAU w Krakowie;

- Archiwum Ośrodka KARTA;

- Archiwum Państwowego Muzeum Auschwitz-Birkenau w Oświęcimiu;

- Archiwum Państwowego Muzeum na Majdanku;

- Archiwum Polskiego Radia;

- Archiwum Polskiej Akademii Nauk w Warszawie (oraz Oddział w Poznaniu);

- Archiwum Sejmu;

- Archiwum Zamku Królewskiego w Warszawie;

- Archiwum Żydowskiego Instytutu Historycznego;

- Instytut Pamięci Narodowej;

- Polskie Centrum Informacji Muzycznej;

- Repozytorium Cyfrowe Filmoteki Narodowej;

- Stowarzyszenie „Archiwum Solidarności”;

- Wojskowe Biuro Historyczne - Centralne Archiwum Wojskowe.

Infobroker prowadząc kwerendę archiwalną może korzystać również z zasobów instytucji polonijnych. Wśród nich należy wymienić te posiadające wyjątkowo cenne zbiory:

- Instytut Józefa Piłsudskiego w Ameryce - Nowy Jork;

- Instytut Literacki Kultura w Paryżu;

- Muzeum Polskie w Rapperswilu;

- Ośrodek Dokumentacji Pontyfikatu Jana Pawła II w Rzymie;

- Polski Instytut Naukowy w Ameryce (PIASA) - Nowy Jork;

- Stała Konferencja Muzeów, Bibliotek i Archiwów Polskich na Zachodzie.

Biblioteki i archiwa stanowią tylko część bardzo rozbudowanej sieci placówek informacji, w której skład wchodzą również instytucje publiczne i społeczne, te jednak coraz częściej preferują nowe formy komunikacji 
z odbiorcami za pośrednictwem takich kanałów przekazu, jak Internet czy telefonia komórkowa.

\section{Konkluzje}

We współczesnych czasach ogromny zasób informacji, intensywny rozwój nauki oraz tempo postępu techniki stwarzają potrzebę istnienia wielu równolegle działających kanałów informacyjnych. Pojawienie się nowego zawodu, jakim jest broker informacji, było odpowiedzią na potrzeby współczesnych społeczeństw informacyjnych. Zaznaczyć należy, że pomimo iż cechą rynku informacji jest fakt, że wprowadza się nań nowe formy i techniki, z reguły bardziej sprawne, szybsze i tańsze, to nie eliminują one dotychczasowych tradycyjnych form przekazu. Na rynku informacyjnym nowe środki komunikacji współegzystują z istniejącymi od początku cywilizacji. Zatem, tak jak druk nie wyeliminował pisma ręcznego, a pojawienie się radia i telewizji nie zlikwidowało słowa drukowanego, tak można zakładać, że pojawienie się nowych źródeł informacji nie doprowadzi do całkowitego zaniku źródeł tradycyjnych.

Kompetentny infobroker musi wykorzystywać całość zasobu informacyjnego. W czasach społeczeństwa cyfrowego, jak pisali pod koniec ubiegłego wieku Bill Kovach i Tom Rosenstiel, wytworzyła się: „[...] kultura niepopartych zarzutów i twierdzeń, która rozwija się kosztem dawnej kultury weryfikacji” ${ }^{40}$. Na rynku informacyjnym pojawiają się nowe zjawiska niebezpieczne dla kultury weryfikacji, jak na przykład anonimowe źródła informacji zapełniające Internet. Już w 1920 roku Walter Lippmann upominał, że: „[...] zarówno publiczne, jak i prywatne poglądy zależą od precyzyjnych, wiarygodnych relacji o przebiegu wydarzeń. Nie to, co ktoś mówi, i nie to, co ktoś chciałby, aby było prawda, ale to, co nią jest, daje właściwy osąd" ${ }^{41}$. Stąd na zawód infobrokera nałożona została wielka odpowiedzialność weryfikacji informacji i aby jej sprostać, konieczne jest dysponowanie odpowiednim warsztatem źródłowym.

40 B. Kovach, T. Rosentiel, Warp Speed. America in the Age of Mixed Media, Nowy Jork 1999, cyt za: A. Briggs, P. Burke, Społeczna historia mediów. Od Gutenberga do Internetu, Warszawa 2010, s. 361.

41 Cyt za: tamże. 


\section{STRESZCZENIE}

Współcześnie Internet stał się wiodącym źródłem informacji, nie można jednak umniejszać roli informacji pozyskiwanych z tradycyjnych źródeł, nie straciły one swojej aktualności i znaczenia. Za właściwą strategię infobrokera należy uznać taką, która uwzględnia techniki wyszukiwawcze typowe dla danego rodzaju źródła. W pierwszej części tekstu skupiono się na metodologii nauki o informacji oraz wskazano miejsce infobrokera w procesie informacyjnym. Jednym z kluczowych aspektów prezentowanej analizy jest przedstawienie wiodących definicji i klasyfikacji tradycyjnych źródeł informacji z zakresu wiedzy historycznej i informatologii. Druga część tekstu odnosi się do kompetencji osoby wykonującej zawód brokera informacji, do których zaliczają się: wyszukiwanie, gromadzenie i opracowywanie informacji z takich instytucji, jak państwowe i prywatne archiwa, biblioteki czy muzea.

\section{Urszula Kurcewicz}

\section{THE IMPORTANCE OF THE Traditional SOURCES OF INFORMATION IN INFORMATION BROKER ACTIVITY}

Though in the present age the Internet is an important resource for gathering information, there are also plenty of significant and helpful traditional sources. The best data collection strategy in information broker activity is one that employs techniques from both. The first part of the text is focused on the methodology of obtaining information. The author points out the place of information broker in the information process. One of the key aspects of the following analysis is an attempt to indicate the main definitions and classifications of the traditional sources of information in a field of historical knowledge as well as in the information science. The second part of the article considers information broker professional qualifications, since for him is important to know how to search, gather and integrate information from institution such as the national and private archives, libraries or museums.

KEY WORDS: information broker, traditional sources of information, information process, archives, special library material 


\section{Bibliografia}

Baczyńska B., Grabarz K., Machlowski S., Jak zostać brokerem informacji? Wybrane aspekty praktyczne, [w:] S. Cisek, A. Januszko-Szakiel (red.), Zawód infobroker. Polski rynek informacji, Warszawa 2015.

Batorowska H., Czubała B., Wybrane zagadnienia nauki o informacji i technologii informacyjnej, Kraków 1996.

Chmielewska-Gorczyca E., Sosińska-Kalata B., Informacja naukowa z elementami naukoznawstwa, Warszawa 1991.

Dembowska M., Dokumentacja i informacja naukowa. Zarys problematyki i kierunki rozwoju, Warszawa 1965.

Dembowska M., Nauka o informacji naukowej (informatologia). Organizacja i problematyka badań w Polsce, Warszawa 1991.

Dominiczak H., Zarys metodologii historii, Częstochowa 1995.

Handelsman M., Historyka. Zasady metodologii i teorii poznania historycznego, oprac. P. Węcowski, Warszawa 2010.

Januszko-Szakiel A., Informacja tworzywem przekazów infobrokerskich. Wybrane zagadnienia, [w:] S. Cisek, A. Januszko-Szakiel (red.), Zawód infobroker. Polski rynek informacji, Warszawa 2015.

Kovach B., Rosentiel T., Warp Speed. America in the Age of Mixed Media, Nowy Jork 1999.

Kula M., Nośniki pamięci historycznej, Warszawa 2002.

Labuda G., Próba nowej systematyki i nowej interpretacji źródet historycznych, „Studia Źródłoznawcze" 1957 , t. I.

Ratajewski J., Wybrane problemy metodologiczne informologii nauki (informacji naukowej), Katowice 1994.

Ratajewski J., Informologia - nauka o informacji, [w:] A. Jarosz (red.), Informacja naukowa, bibliotekarstwo, zagadnienia wydawnicze, Prace Naukowe Uniwersytetu Śląskiego. Studia Bibliologiczne, t. V, Katowice 1992.

Sosnowska K., Pomoce do nauczania przedmiotu „Opracowanie dokumentacyjne źródet informacji”. Ćwiczenia. Sprawdziany, Warszawa 1980.

Świderska G.K. (red.), Informacja zarzadcza $w$ procesie formułowania i realizacji strategii firmy. Wyzwania dla polskich przedsiębiorstw, Warszawa 2003.

Topolski J., Metodologia historii, Warszawa 1984.

Żmigrodzki Z, Bibliografia. Metodyka i organizacja, Warszawa 2000. 